\title{
UNRULY AFFECTS: Attempts at Control and All That Escapes from an American Mental Health Court
}

\author{
JESSICA COOPER \\ Princeton University \\ (D) http://orcid.org/0000-0001-7599-6736
}

It was at the end of the second day that I spent with Harriet - before she threatened suicide, but after she had told me that court supervision "feels like death" - that she suddenly started to speak about the land. ${ }^{1}$ We were sitting in a parking lot at the time. It was hot, and the vast expanse of asphalt before us wasn't helping things. I kept sucking on the dregs of an iced tea, trying to get the last bits of melting ice out of my cup, and Harriet had already twice refilled her Nalgene from a hose on a nearby patio. Summer had come early to Northern California, in full swing by April of 2015. After a few hours of conversation, Harriet and I had fallen silent, which felt right in some way - the air between us was already thick with the weight of the heat, if not dialogue. Until Harriet suddenly punctured the silence with a declaration that, to me, seemed out of the blue: "I am of the land, and the sea, and the air."

Harriet's origin statement hung in the space between us. In the time that has since passed, Harriet has elaborated on her assertion, integrating it into her identity as a pantheist, heathen witch. But at the time of her first announcement"I am of the land, and the sea, and the air" - I was caught by surprise, in part because Harriet is not herself "landed." Put differently, Harriet does not participate in a regime of land ownership. We were sitting in this parking lot next to 
her car, a dinged-up Prius with paint chips and dents and erosions in its antiwar and LGBTQ bumper sticker-covered metal shell, because this is her home. She had selected this particular parking lot as our meeting point because it offered the most shade in which she could park to protect her co-inhabitants: Fluffy, Megabyte, and Vlad, all cats. Transportation, bedroom, storage shed, litter box: the Prius is everything.

Since 2014, Harriet's life has revolved around the Prius. Because of the cats, she tends to come back to this shady spot in Alta Vista, a wealthy enclave in Silicon Valley, where she believes police are less likely to bother her than in areas more notorious for their homeless encampments. ${ }^{2}$ At night, when the tech engineers return to their Alta Vista homes, she relocates to parking lots in strip malls on the outskirts of town, also for the purposes of evading the police. Harriet's mother is homeless and lives out of a Camry. The two will park the Prius and the Camry next to one another at night for safety. In their own way, they commute, in the inverse direction of all of the Teslas and Porsches, driving out of the bedroom community at night and back in by the morning light. Harriet has befriended cafe owners and will leave the cats in the car-windows cracked, sleeping bag spread out over the headrests to create even more shade beneath a makeshift tent — while she drinks free coffee and uses free Wi-Fi to update her Facebook page and FaceTime an interested anthropologist from her iPhone. She takes walks. She scavenges. Though Harriet is in her early thirties, she has found a group of genderqueer kids from the local high school who like to cut class and hang out with her, voicing admiration for her life as a transgender woman who opts to retain a masculine physical appearance, beard and all.

And sometimes, Harriet will drive the Prius with the cats and her mother over the hill to the Santa Clara county courthouse, the building where Harriet and I first met. Harriet is a client of the county's mental health court, a criminal courtroom that attempts to offer community care in place of incarceration to offenders whom the state believes to have mental health problems. Clients, like Harriet, regularly return to court for a review of their progress toward mental health. Failure to clinically progress, as determined by the attorneys and clinicians who staff the mental health court, can result in legal sanction. Most clients are homeless for at least part of their time in the program.

In this essay, I demonstrate how Harriet's perpetual movement confounds the mental health court's claim to jurisdiction, a claim that I figure as an attempt to ensnare Harriet. I repeat: an attempt to ensnare Harriet. Like others who have studied the often-devastating effects of state violence, I register the ways in which 
states train their attempts at control on people who cultivate or otherwise possess subjectivities that states find difficult to govern. From examining South Africa's production of criminality and its punishment to authorize the state's existence (Comaroff and Comaroff 2016) to exploring Australia's development of racist policies to quietly snuff out Aboriginal ways of life (Povinelli 2011) to revealing the "murderous" quality of "anonymous care" in the Canadian Arctic (Stevenson 2014, 73), ethnographic scholarship has flagged the perniciousness of state violence and suggested the urgency of political engagement. My concern, however, is that scaling up from particular accounts of state violence to state power writ large overestimates the efficacy of state action. Just because representatives of the state would like to punish those who deviate from norms does not mean that they are able to do so. Even successfully implementing a state system to punishto make devious subjects more governable - does not mean that such lessons are internalized. Attempts at control, even those undertaken by states, sometimes fail. I foreground the suppleness and indeterminacy of state power by thinking through attempts at control - attempts that may succeed or fail but that are inevitably muddled by the people at whom they are directed.

Courts' claims to jurisdiction are legal attempts at control that work chronotopically, acting on both time and space. Through jurisdiction, the law fixes people in time and space to make claims about their capacities for action and the responsibility they assume for their conduct. Harriet's mobility disrupts the mental health court's attempt to "fix" her, to stabilize a psyche that the court takes to be disordered through the inculcation of a particular arrangement of space and time, with attendant implications for action and responsibility. Harriet's refusal of psychic or physical stability, then, challenges jurisdictional claims to authority from the inside out. In legally claiming jurisdiction over Harriet, the court makes certain demands of her, namely, that she appear at court on particular days and at particular times. Sometimes she satisfies these demands and at other times she does not; her unwillingness to allow the court's plans for her time to overwhelm other considerations, such as spending time with her mother, or with her cats, or by herself should she so choose, rejects the law's narrative that authority is generated through the fixing of time and space. In other words, Harriet refuses to be territorialized (see Deleuze and Guattari 1987), undoing the state's claims to legitimately govern her through her own mobile manipulation of terms produced by the state's invocation of jurisdiction. She defies fixity in her refusal to be still. 


\section{THE OLD HOUSE}

Harriet and her mother have not always been homeless. As one might guess from her Prius and MacBook Air and college credits and iPhone and veganism and very particular attitudes toward third-wave coffee roasting, there was a time before. As she tells it, Harriet never expected to live in parking lots. She grew up in a middle-class home, not too far from Alta Vista. While she might be "of the land, and the sea, and the air," she was born in a nearby hospital and taken home to a house on a suburban cul-de-sac in which she lived with her mother until 2010, when unemployment and the rising costs of living in the area caused the bank to repossess the house. By the time the bank evicted Harriet and her mother, her parents had been separated for several years, and her sister had moved out and into a home of her own with a new husband. Only Harriet and her mother were left.

The house is important, not simply because it establishes homelessness as an anomaly in Harriet's life but also because its address places it within Santa Clara County. It is important because the house is the scene of the crime for which Harriet was arrested and convicted. It is important because the repossession of the house marks the starting point for Harriet's life with the mental health court. If Harriet marks her own origin as "the land, and the sea, and the air," the origin of her life with the mental health court began with the dispossession of her home. As her relatively stable socioeconomic life began to disintegrate, deep memories - perhaps that part of her "of the sea" - began to flood over her. She remembered that her father had killed a child, a friend of hers from elementary school, and had buried the body beneath the stairs. She remembered being asked to help with the handiwork: getting a hammer, holding nails, shining a flashlight, while her father dug a pit in a closet under the stairwell. When she called the police to tell them that her father had murdered a boy twenty years earlier and that the corporeal evidence of the crime lay buried beneath the staircase that the bank was about to take away, a cruiser arrived at the house and took Harriet to the psychiatric ward at the county's public hospital. When she was released a few weeks later, she went back to the home in which she had grown up. Her sister and brother-in-law had started to pack boxes. The house was still foreclosed upon. But before Harriet and her mother left the home, those cruisers would be called back, this time by Harriet's sister, this time to a space that the police believed to be a crime scene, this time of Harriet's doing.

The legal term that we might use to locate the old house vis-à-vis the court is jurisdiction. The house's location determined which police agency responded to 
the 911 calls, to which public hospital Harriet would be taken, which county psychiatrists would be making decisions about her health care, which psychotropic medications would be available for use. The place of the house had significant legal ramifications. Like Harriet herself, jurisdiction is, in part, of the land. Jurisdiction's partial stake in the land is instrumental, in the sense that claiming land is the way that the law works to establish authority, as made violently clear by the jurisdictional land grabs of colonial law (Benton 2009; Benda-Beckmann and Benda-Beckmann 2014). And, as Shaunnagh Dorsett and Shaughn McVeigh (2012) note, when a state claims jurisdiction, the state performs a double move, simultaneously delimiting a territory and positing itself as the rightful authority to govern said territory, a double move that, as Jeffrey Kahn (2017, 7) writes, possesses "cosmological, or world-ordering, properties."

This sovereignty is exercised sneakily and stealthily. Mariana Valverde (2009, 2014, 2015) demonstrates how jurisdiction constitutes a political technology whose genius lies in the masking of its own politics. The "game of jurisdiction" establishes the technocratic rules of "the governance of legal governance," such that politics are "rendered invisible" (Valverde 2009, 155, 144, 141). Justin Richland (2013, 214) describes this practice as a sort of shapeshifting, the conversion of "ontological questions about the essence of legal power into pragmatic ones." When funneled through arguments over jurisdiction, questions about legal authority are made technocratic rather than political. In other words, Valverde and Richland show how the two-step identified by Dorsett and MacVeigh is actually a triple step: first, the state asserts control over a territory; second, it silently implies that its control over a territory renders its authority just; and then, third, it erases the connection between the rightfulness of the state's authority and its territorialization, such that the rightfulness of the state's authority appears to stand on its own. Claiming territory is a silent stand-in for claiming legitimate power.

But jurisdiction is not so simple as determining an address. After all, Harriet no longer has one. The old house is old. After she was arrested at the old house for the crime to which she eventually pleaded guilty, Harriet was confined in the county jail. When her case was transferred to the county's mental health court, the court offered her release from jail in exchange for a series of conditions designed to contain her in the community. The mental health court tried to prevent her itineracy by offering her public housing or a bed in a residential psychiatric treatment center. Neither option was available. All the court could offer was a bed in a temporary homeless shelter, but the shelter would not let 
her cats in the building and she would be forced to live with men, based on her sex. These facts made the offer of a shelter bed a nonstarter. Harriet took to the streets.

Absent a place, a space, to put Harriet, the mental health court issued a different demand. She was to consistently arrive at a particular place (the mental health courtroom) at a particular time (every six weeks), or fall in violation of the terms of her probation. The court offered her those terms of probation in lieu of a different type of spatiotemporal confinement: a prison sentence. By imposing terms of probation, which the mental health court professionals with whom I worked considered to be a release from what they called the "cruel conditions" of custody, the court supplanted confinement-by-incarceration with confinement-by-appointments. Were Harriet to fail to show at her court hearings or any other social service meetings arranged by the court, the judge could issue a warrant for her arrest, swapping yet again the particular form of spatiotemporal control that the state elected to exercise over Harriet.

As much as jurisdiction is inescapably partly about land, then, it is never only about territory. In explicitly circumscribing space, jurisdictional claims fix time. As Carol Greenhouse (1996, xi, ix) suggests, time is a "classic anthropological question," specifically because it functions as an emic "surrogate for specific questions of power, authority, and legitimacy." Extensive anthropological research has maintained that time is a cultural concept, the particular construction of which makes possible and exposes different theories of agency and authority. Or, as Deborah Thomas $(2016,179)$ explains through her historical-ethnographic work on life in garrisons in the Caribbean, considerations of temporality matter for understandings of sovereign violence because "normative conceptualizations of being and becoming" are "undone and remade" by "the pressures and inequalities of modern time.” ${ }^{4}$ In matters of subjectivity and agency, then, time and space cannot be pried apart. Based on her fieldwork with a population that she identifies as homeless and schizophrenic, Anne Lovell (1997, 355) argues that temporality is the "essence" of a reflexive subjectivity, as the organization of various events in narrative time is what renders everyday life legible in an "existentially meaningful" way. In her reading, it is the socially unusual "temporal and aesthetic devices" of schizophrenic narration that "preclude the constitution of identity through culturally sanctioned narratives" (Lovell 1997, 356), thereby maintaining an existential distinction between the subjectivities of those who are schizophrenic and homeless and those who are not. In her engagement with one schizophrenic and homeless man she calls Rob, Lovell leverages the conjunction of space and time 
as a methodological intervention; when Rob's flattened verb tense made it difficult for her to understand his self-narration, Lovell (1997, 362, 361) "supplanted" Rob's socially illegible temporal structure with "categories of space” by spatially mapping his "voyage" through homelessness, so as to yield a timeline. The push and pull of Lovell's fieldwork mechanics reveal the ethnographic imperative to consider time and space in tandem.

The imbrication of time and space ought not be surprising: this is what Mikhail Bakhtin (1981) refers to as a chronotope. In analyzing the emergence of the novel, Bakhtin $(1981,84)$ highlights the "intrinsic connectedness" of time and space. Bakhtin positions the chronotope, or the amalgamation of time and space prior to their theoretical distinction, as the motivating force for narrative and hermeneutics. Bakhtin (1981, 258; emphasis added) is not restrained in his analysis: "Every entry into the sphere of meaning," he writes, "is accomplished only through the gates of the chronotope." In trying to pin the slipperiness of jurisdiction, Valverde $(2014,2015)$ has productively invoked Bakhtin's chronotope. Following Bakhtin, she presumes that space and time are always conglomerated; in speaking to space, jurisdiction makes claims on time, but only silently. Calling on the chronotope helps reveal what the transcript of jurisdictional argumentation will not.

Valverde's use of Bakhtin exposes the backstage operations of jurisdiction, those silent implications of articulated claims, and engages Bakhtin primarily as a theorist. But Bakhtin does not just theorize in a vacuum; he does so using novels. The matter of Bakhtin's theorizing is significant. As Bakhtin (1981, 99, 152) moves through various genres - from the Greek romance of "adventure-time" to the medieval romances of chivalric "everyday adventure" - he emphasizes different possibilities for action. A novel's chronotope determines potential plotlines. The formulation of time and space invoked lends itself to specific narratives. Different plots imply different compositions of agency for the characters working within the narrative.

Consider Bakhtin's (1981, 87-88) explication of Greek adventure-time. In sum: boy meets girl, boy and girl fall in love and intend to wed, boy and girl are separated, boy and girl undergo various travails, boy and girl reunite and wed. This plotline is sustained by a particular formulation of time and space. For this plot to function, the story demands "an expanse of space" that is "interchangeable" and a time that is "empty" and "leaves no trace" (Bakhtin 1981, 99, 100, 91, 90). The characters' adventures over space and time have no impact on their psychological development. The beginning and end points of the narrative are homol- 
ogous; the trials of the intermediary moments may just as well have never transpired (Bakhtin 1981, 89-90). This is an argument about agency and subjectivity: plot is something that befalls adventure-time's protagonists. They do nothing to participate in it and are unaltered by it. Encounters or missed encounters between characters but orchestrated by Fate determine plotlines in adventure-time. The meeting: an encounter, or missed encounter, in which the "temporal marker" is "inseparable from the spatial marker" (Bakhtin 1981, 97). Meetings only happen in the alignment of space and time, near-misses in their divergence. And while I am not arguing that the mental health court employs Greek adventure-time in the present day, the court's own regime of legally mandated meetings, appointments, and hearings likewise teases out a figure of a subject through the configuration of agency.

These are the stakes of "the game of jurisdiction" (Valverde 2009, 155): by claiming an explicitly territorial and implicitly temporal jurisdiction, the state promotes a theory of agency in which the object at the center of the claim to jurisdiction (here, Harriet) can be held responsible for a series of events. Moreover, in this particular chronotope, the state casts itself as the best protagonist to hold its jurisdictional object (again, Harriet) accountable. In fixing formulations of time and space, invocations of jurisdiction fix relations of moral authority, such that one party always has the upper hand. When jurisdiction supposes that space can be determined and time is linear, it tells a particular type of story with a particular type of plot. The chronotope invoked by the court's claims to jurisdiction tells a story in which individuals are atomistic and agentic. When said agentic individuals violate the social contract, it falls to the state to hold them responsible. And while no one with whom I worked ever mentioned Bakhtin, discussions of meetings and appointments, those fused spatiotemporal markers, and their misses were a constant topic of conversation, thereby patterning discourse and subjectivity in a particular way (Bakhtin 1981, 97). The individual is the unit of analysis. An action can be traced back to an individual who can be held responsible through linear time. Relationality and plurality do not fit in the court's rendering of time and space. The plot is one of an individual moving through the world with intention and agency.

Plotting space and time as axes on a chronotopic grid by requiring presence at a particular place at a particular time, as the court required of Harriet, is an attempt at control. In the eyes of those who staff the mental health court, it is a benevolent attempt at control. Martha, one of the court psychologists who had been working with Harriet for several years by the time I arrived, was sympathetic 
to many of Harriet's troubles. When I asked Martha about Harriet, she would sigh. "It has to be hard," she would say, "to grow up as a transgender kid, on top of everything else." I took this "everything else" to refer to Martha's perceptions of what she called "Harriet's personality problems," problems that Martha interpreted in a psychiatric, diagnostic kind of way. But Martha would also get frustrated, tired of explaining over and over and over again to Harriet why she had to show for her court dates. "How hard can it be?" Martha would mutter to me, after one or several such explanations to Harriet. "I know it isn't easy to get here, but it has to be easier than a prison term. That was her other option."

Some of Martha's frustrations, she told me, were because Harriet "had it pretty good" compared to many of the court's other clients. Harriet was white. She had a college education. Outwardly, because of her self-presentation, she looked like a white man who owned a Prius. You could not see Harriet's gender, or the fact that she was constantly drinking coffee to stave off the hunger pains that would inevitably arrive from not having access to anything to eat, or her expired car registration and lapsed insurance. Unlike many of the court's other clients, people who lacked both homes and cars and therefore spent nights outside, Harriet had some form of shelter. And Harriet's shelter had a clock that showed the time and date. She had a digital calendar on her iPhone, something that could not be said for many of the court's other clients, who would have to ask someone or look for a public clock or newspaper to find out what day and time it was to know if they had court. No, Martha would acknowledge, the cost of gas was not negligible, but Harriet only had to drive a handful of miles. Compared to many of Martha's other clients, who relied on the few bus tokens that Martha would distribute to them for transportation for the entire month, if Harriet failed to appear, it was her failing. Martha's chronotope posited a linear temporality through which individuals could be responsible for appearing in certain places when required to do so, especially if they had any material means. The plot mobilized by Martha implied a particular way of moving through time and space and a subject who could be held responsible for deviations from this type of movement.

It was not so much that Harriet rejected or disagreed with the chronotope that Martha and the rest of the mental health court professionals attempted to foist on her. In place of explicit conflict, Harriet expressed bafflement and frustration. She never understood, she would tell me, her voice squeaky and distressed, how the court could expect her to physically be in one place at one time. She frequently had migraines and could not sleep, an insomnia exacerbated by 
trying to sleep in the Prius's reclined driver's seat. Sometimes she was too tired to get to appointments on time. She told Andie, another court psychologist, that sometimes she could not come to court because of the pain from her fibromyalgia. Andie had walked away from that conversation in the courtroom, turning to me to say, "Now, that's just bullshit." Andie had rolled her eyes and rubbed her palm against her cheek, a gesture that I understood as a reference to Harriet's beard. "You can only have fibromyalgia if you have a uterus. This is just pure hysteria." Andie did not note the irony of her turn to yet another (debunked) affliction of the uterus. If the court was really trying to help her, Harriet would say to me, then they ought to understand everything else going on in her life, things that sometimes made it impossible for her to get to court. Ironically, the court professionals agreed: as a mental health court, as opposed to a "normal" criminal courtroom, the court attempted to claim jurisdiction over all aspects of Harriet's life, not limiting itself to only attempting to control criminal conduct. Yet through its various appointments and meetings, the court attempted to provide order, to neatly and therapeutically arrange the various aspects of Harriet's life, through the insistence on their spatiotemporal plotting.

But that's the thing about plot. If all a narrative achieved was to cast characters into particular formulations of space and time, it would be an awfully dull story. A plot feels like something. Plots generate affective engagements with their objects. They express “mood,” as Mariana Valverde $(2015,78)$ glosses Bakhtin's argument about affect. A plot creates an atmosphere - that cluttered and unstable zone of interaction between land and air. Timothy Choy and Jerry Zee (2015, 211) propose the atmospheric as an analytic frame that entails "a way of being suspended," not in a void, but instead with attention to interaction, friction, attraction, or, "how things lift and settle in mediums." Suspense is always mediated, involving potential interactions. The individualized narrative demanded by the court's claim to jurisdiction cannot capture the contingencies and uncertainties of atmospheric relations. Writing of ordinary life in Appalachia, Kathleen Stewart (2011, 449, 452) calls atmosphere the "sentience of a situation," a "lived affect" that exceeds fixity and individuation through "an attunement of the senses, of labors and imaginaries to potential ways of living through things." Jurisdiction is a game, then, with unintended consequences. The chronotopic moves that allow the court to posit a theory of agency and accountability generate narratives that give way to an affective atmosphere that exceeds the court's grasp. Harriet's physical, temporal, and psychic peripateticism, made material by the roving of her Prius, focuses attention on those "potential ways of living," as Stewart (2011, 
452) would say. Her life points to the otherwise, to a plot that she scripts and improvises differently than does the normative work of law. Her alternative formulations of time and space give rise to different understandings of agency and accountability, frequently in uncomfortable tension with those understandings of the court that supposes itself to fix her.

\section{THE PILLS}

A few times, over the course of the year and a half that Harriet and I spent together, she went missing, wandered away, out of touch. Sometimes she would go missing from me, not replying to my messages. ${ }^{6}$ Sometimes she would disappear and not show up to her court hearing on the appointed day and time. I tried to respect Harriet's understanding of time and space, an understanding that, for me, was sometimes too absent, when she would go off the grid and not show for an arranged get-together, and sometimes too present, texting and emailing late into the night. But I worried that the court would penalize her for her absence, which was technically in violation of her terms of probation.

One day, about six months after we had met, Harriet did not show for court at all. I had watched the hands of the always-fifteen-minutes-fast court clock tick to its own off-beat metronome. Instead of progressing minute by minute, the clock would violently slam a minute forward and then fall a half-minute back, only to repeat the lurch some seconds later. The judge took Harriet's case last, with an eye roll and a glance to the clock, announcing Harriet's absence while picking up the case file. "Well," the judge huffed, "Evan isn't here. But I have gotten several very long, very convoluted emails from him.” Evan: Harriet's birth name, another legal label to which she did not respond. Him: a pronoun with which she did not identify. In her absence, the court spoke about a person other than Harriet. The judge began to read Harriet's email aloud and then turned, instead, to summary. The document was too long to read word by word. "Well, he's very sad, the cats, the car . . . he says he's in pain. . . ." The judge squinted to read Harriet's language, quoting her aloud: “'Time is not in the linear order that you perceive.'" He recoiled from the letter with a smirk, as the others in the courtroom, a chorus of psychologists, attorneys, and clerks, laughed uninhibitedly. I felt myself pale and stared at my notebook, knowing the next line, knowing what was to come-I had been blind-carbon-copied on the original email. The judge leaned back in: "'Time for me is cyclical and random. . . ."”

Laughter overtook the letter. Harriet's attorney choked out a few words between the gales of guffaws: "Cyclical and random! Yeah, same here. Look at 
the cyclical nature of the cases in here." It was a joke, but it need not have been. Harriet's description was all too comprehensible. A different understanding of time, that nonlinear, cyclical, random version put forward by Harriet in her absence, lent a very different interpretation of the court's authority and efficacy. Legal interventions in the name of linear clinical progress lost their warrant. The artificiality and arbitrariness of Harriet's own chronotope uncomfortably pointed to the artificiality and arbitrariness of the court's. They were equally valid and equally invalid.

And then there was the rub: the way in which Harriet's chronotope was, in some sense, more adept at explaining the court's own patterns. Her attorney had noticed: Harriet's cyclical chronotope could better account for the constant recycling of clients and cases through the court's doors. Clients would complete the program, be declared "graduates" by the judge at a scheduled ceremony to mark their internalization of the court's understanding of personal responsibility, only to end up getting rearrested and returned to the mental health court in a matter of weeks or months. The chronotope with arguably the better explanatory power invalidated the normative force of the narrative to which the court clung. Time is linear. Space is definable. Individuals are the agents of their life histories. The court holds them responsible. When you refuse the first premise, what happens to the claims that follow? They might be seen as laughable. They might be made the punch line of a joke. Or the punch line of a joke that is not really a joke. Harriet's attorney would later tell me that she found Harriet's emails "genuinely" amusing. But she would also say this: "Sometimes you just have to laugh at it all." Sometimes it is too much, sometimes you realize that you cannot possibly help everyone, sometimes you see the inevitability of your own failure at a game that you started.

The court, too, is hamstrung, caught in the same jurisdictional game through which it attempts to catch Harriet. The courtroom in which everyone laughed is a courtroom with a social justice mission; it tried to fix Harriet by fixing her, attempting to stabilize what the court perceived as Harriet's psychiatric distress through interaction with the court's interventions. Jurisdiction, for the mental health court, is the legally required first step in the long game of court-mandated mental health care. Settling the question of jurisdiction legally allows the courtroom to coerce, to stabilize, to fix over Harriet's objections. Were the mental health court not to assert legal jurisdiction, it would not be a party to the game. There would be no legal game at all. The implications of the legally mandated first move register affectively as discomfort, or perhaps as humor, even as court- 
room professionals maintain their logical coherence. In other words, if chronotopes fix relative positions of moral authority, and if claims to jurisdiction present the state as said authority as a foregone conclusion, mental health court attorneys and clinicians are well aware that this is an authority that they might live up to in name only.

The law's rules for playing the game of jurisdiction falter in the face of Harriet's movement; her itinerancy uses the chronotopic terms of jurisdiction to point to the game's own loopholes - sentient situations, to paraphrase Kathleen Stewart $(2011,449)$ — that the court cannot address. Movement, here, is physical and psychical. Harriet's itinerancy and physical wandering stand in for the less tangible ways in which she declines an identity as a stable and individuated subject, as the court wishes for her. Her movements over the skin of the land are proxies for movements in the sea and in the air, movements in memory and psyche, which also cannot be contained by the court's understanding of the individual. What is it about Harriet's movement that, for now, escapes jurisdiction's grasp?

Think of a film, suggests Gilles Deleuze (1986). The montage, the sequence of images and their movement, is radically different than a consideration of each frame. The movement does something. To explain the sublime value of movement, Deleuze turns to what Henri Bergson (1998) saw as the crisis of psychology brought on by the invention of moving pictures in the early twentieth century. As Deleuze understands Bergson's fascination, movement is enigmatic because it reveals the inextricability of time and space. Movement, Deleuze takes Bergson to say, cannot be comprehended purely in spatial terms. If "movement is different than the space covered" (Deleuze 1986, 1), time is the conceptual tipping point. Thinking temporally, Deleuze $(1986,1)$ argues, reveals that "space covered is past, movement is present, the act of covering." Whereas space can be parceled, movement is "indivisible," such that the act of dividing the duration of movement changes the movement "qualitatively" (Deleuze 1986, 1). Said differently, movement draws attention to the chronotope and makes possible an interrogation of the normative conditions, such as agency and authority, which extend from a particular formulation of time and space. By moving, Harriet rejects the court's parsing of her coordinates of self.

But are mental health courts not designed to move with their clients? Is the jurisdictional game played by mental health courts not different than the rules to which other criminal courts subscribe? Rather than plainly assigning guilt or innocence, the mental health court aims to identify convicted individuals whom it believes to be mentally ill and to move them to a condition of mental health. Is 
movement not, then, integrated into this set of rules? This type of movementmovement pinned to one position or another - is not movement at all, Brian Massumi (2002) would argue. Offering his own reading of Bergson (1998, 308310), Massumi presents the paradox of Zeno's arrow. The flight of the arrow cannot be reduced to the points through which it passes. Thus the position of an arrow is not a captured metonym of movement, only "movement's residue" (Massumi 2002, 7). Adducing a position, be it guilty or innocent, mentally stable or mentally unstable, "begins by subtracting movement" (Massumi 2002, 2). Moving with an end point in mind is, for Massumi (2002, 3), "a pinpointing, a zeropoint of stasis," replacing "movement itself" with "predefined beginnings and endpoints." The type of change that the mental health court associates with progress is not movement at all. A known trajectory is territorialized, contained by regimes of power. Harriet is unmoved by the court's desired trajectory. She does not fully know, nor does she fully remember. The beginnings and the ends are unclear.

Through what substance does Zeno's arrow fly? Massumi presents a pristine sort of movement, as if the arrow soars through empty air. If Zeno's philosophical arrow moves through air, Harriet's experiences move through an atmosphere, that space between land and air, that space, as Timothy Choy and Jerry Zee (2015) remind us, that is filled with materials, assemblages, constellations of relations within which life can be suspended. For Harriet, movement, however cyclical and nonlinear, is never unencumbered but always weighted by her relationships to others, those things that make it impossible to isolate, individuate, or control her. The social webs that suspend her offer her escape, modes of relation that the court cannot anticipate or control. She moves around, from shady patch to shady patch, to best care for Fluffy and Megabyte and Vlad. She moves up and down the highways, from one county to another, to be with her mother, even though the court has forbidden her to leave Santa Clara. Affect makes the atmosphere thick, sticky, muggy, like the air that filled the space between Harriet and me on that day when we were silent, until she said that she was of the land, and the sea, and the air. The social bonds of the atmosphere are adhesive in a way that is transportable, such that even if you manage to escape, to leave one sentient situation for another, a part of whatever that other experience was comes along for the ride. The court's assumption that air is thin and navigable cannot account for the heavy headwinds of affect that one finds in the atmosphere, the love and care that Harriet feels for her family, offering her an escape from the court's attempt to guide her movement. 
It was in the middle of one of the days that we spent together - not long before the day that she did not show for court, but after her mother had attempted suicide - that we sat down in the grass of the park where she had learned to swim and rollerblade with her sister when they were children. In a different time (five years before), but almost in the same place (in that old house), Harriet had put her mother in an asphyxiating chokehold. "After all of these years, I still can't remember putting my hands on my mother," she told me, in between bites of Kung Pao tofu. She went on:

I remember standing in the doorway and seeing this figure hurting my mother, like really going at her. And when I saw that figure attacking her, I wanted to help her, I wanted to help my mom. I can kind of remember taking my hands off of my mother's throat, but I can't remember putting them on her. Earlier in the day, I remember, I said to my mom: "Leave me alone, go to my sister's." I wanted her out of the house. I was feeling really unstable, and she wouldn't leave me alone. I think that she wanted to take care of me. . . . It doesn't really make sense to me? Why would I have attacked my mom in front of an open door? Instead of letting her leave? I guess, I closed the door? After I attacked her. She said that she wanted to leave, that she wanted to go to the hospital because of her throat because she was scared of me and couldn't breathe, even after I had let go, but then I didn't want her to leave. I was afraid of myself. I needed her. At some point, she called my sister and my sister and her husband came over to get my mother. I was terrified of them when they got there. I screamed. I actually hid in the bathroom. And then, when they were about to leave, I ran out and asked them to take me to the hospital. My sister was protecting my mom, she wouldn't put us in a car together, so she called 911 again, thinking that the police would come for me and take me to the hospital, like they did last time. But this time they booked me in the county jail.

The Santa Clara County district attorney charged Harriet (Evan, the charges read) with elder abuse.

Harriet spent six months in the county jail, on the psychiatric stabilization floor. She says that she was in a straitjacket, by which I think she means a garment that the jail psychologists call "Ferguson garments," shirts made out of cloth that is thick and plasticky and inflexible, designed so that incarcerated people cannot rip them and turn them into nooses. She says that they keep the padded cells cold and won't give inmates sheets, again so that these cannot be turned into 
nooses. She collect-called her mother daily. Those calls are managed by a private company contracted by the county jail; Harriet's mother told me that they cost close to $\$ 20$ for a fifteen-minute phone call. Harriet's mother eventually lost her part-time job because she was taking so many days off to visit her child. Between the calls and the gas and the loss of income, Harriet's mother soon found herself in a financial hole. Part of Harriet's court-mandated mental health treatment was a domestic violence class. She was required to go for fifty-two weeks, though she never completed the program. Harriet's mother, or, as the court would say, “Evan's victim," was paying for it. At a cost of $\$ 20$ per session, at some point the money just ran out.

Harriet spent five years on probation, which she says was almost more difficult than being in custody because she was never clear on the rules. She knew, however, that some of the terms of her probation prevented her from associating with her mother, terms that she flagrantly violated. After Harriet had to give up the tent that she had pitched in a friend's mother's yard for shelter, her mother insisted that they roam together, live together, their cars alongside one another. The day that Harriet went missing, after she did not show in court, after the jokes about time, after the stomach-churning laughter, the district attorney cut into the rip-roars with a solemn crane of his neck: "That mother, though . . . there's something . . . creepy. He and his mom are very . . . enmeshed." The probation officer called their relationship "pathological." On this, everyone could agree; it wasn't even funny.

To the court, Harriet and her mother are, first and foremost, a perpetrator and victim who ought to be kept apart, differently spaced. To Harriet and her mother, they are, first and foremost, a mother and a child who can only survive as a unit, moving about together. The court might try to understand Harriet as an individual, so as to ostensibly improve her mental health, but it is incapable of understanding her relationally, as she understands herself. The court cannot apprehend that excessive affect through which Harriet understands herself and her mother. The court's formulation of jurisdiction and its creation of individuated subjects reach an impasse at the moment of the social. The affect that lies beyond the court's comprehension is an atmosphere inhabited by Harriet and her mother, a chronotopic amalgam that yields a particular feel: rage, dependence, love.

Harriet had been having a rough week before her mother downed that bottle full of pills. Harriet had missed yet another meeting with her probation officer, sick of being told that she couldn't spend time with her mom, but she grew worried that she would be arrested for failing to show. She found, back some- 
where in her trunk, an old bottle of pills that she had received from a clinic a few weeks earlier, moved it to her messenger bag, and waited until the weekend. If she did not feel better about things then, she told herself, she would put the cats in the Camry and go somewhere in the woods to take the pills, "to end things." But on Thursday, Harriet told me, her mother took the pill bottle out of Harriet's bag and downed its contents. Harriet found her mother, laid her down in the back of the Prius with Fluffy, Megabyte, and Vlad and drove them all to the nearest hospital. Harriet said that she was seething the whole ride, more angry than scared. Those pills, that suicide, they were meant for her; her mother had stolen them.

As we sat together in another park, Harriet told me she knew why her mother had done it: "Every time she does something like this, she knows that I go into crisis mode. I can kind of hold it together. With all of the adrenaline, I'm slightly functional. She did this to me." I imagine that her mother would have said it slightly differently: she did this for me. But that wasn't how Harriet put it. Her mother had been more successful than the mental health court in pigeonholing Harriet, in forcing Harriet into a particular plot point. The place into which her mother had cornered her was one we might take as a nonnegotiable beginning: her mother had forced her to stay alive. Even that, for Harriet, was uncomfortably overdetermined. She wanted the option to escape from life itself. Back in the park, Harriet rubbed her temples, her jittering fingertips tracing her beard down to her chin, and then, decisively, she spat in the grass: "Fuck her."

\section{THE PLASTIC PANE}

After five years of attempting to manage Harriet, the mental health court played the last card it had in this game of jurisdiction: it ceded authority. The court decided to end its engagement with Harriet on the day she did not show in court. One of the social workers had finally shrugged: "He seems kind of at baseline, and I don't really see him getting any better." The last move they had to play was to declare Harriet mentally stable, to declare her a graduate of their program. Doing so would imply that the court had played out its own game, that they had moved Harriet in their determined trajectory, that they had fixed her. The court transcript reads as though the court had heroically prevailed, having provided therapeutic order to disorder of all sorts. After the stenographer left the room, all of the attorneys and clinicians admitted to having given up.

It could have gone otherwise, of course. In response to Harriet's stubbornness, her persistent rejection of the court's demands to internalize its operational 
chronotope, the court could have doubled down by intensifying her treatment plan or throwing her back in jail. On the court's terms, they had the authority to do so. And, had Harriet been a person of another race, or, for that matter, dirtier, more obviously homeless, someone whom the court might have deemed more vulnerable based on external appearances than Harriet, who appeared as a white man with some means, perhaps the court would have done so. Maybe, under other social circumstances, the court would have given up less easily. But, as it stood, Harriet was not responding to the services that the court attempted to provide her. Court staff doubted that incarcerating Harriet would do much to help stabilize her and, besides, at this point, at least, Harriet had only ever behaved violently toward her mother, so Martha and Andie did not believe her to threaten public safety. Treating her or jailing her for her refusal to come to court, the judge explained to me, would cost precious resources, effectively taking those resources away from another client who might better use them. They thought that Harriet could avoid arrest on her own, in part because of her whiteness and class background - it was better to expend resources elsewhere.

And then there was the observation that went unannounced, unarticulated by court staff: keeping Harriet's case in the courtroom, witnessing her defy the court's attempts at subjectivation while still somewhat engaging with its services, would undermine that chronotope at the heart of the court's procedures, the faith that getting someone to show up at the right place at the right time would engender authority. Keeping Harriet around would showcase the impasses of the court's logic, those parts of Harriet's story over which the court lost narrative control. Getting her out, particularly in light of the court's determination that she was not a threat to public safety, would keep the court's narrative intact. They had gotten her to sometimes appear at some places and, at the end of the day, the court could say that she was nonviolent by the time of her graduation. Never mind that court staff had never considered her a threat to public safety: it was as true at the end of mental health court adjudication as it was at the beginning, and it better served the court's authority to declare it at the end.

Remember Harriet's email: "Time is not in the linear order that you perceive. Time for me is cyclical and random." Six months after her graduation, Harriet is again confined to a jail cell. His graduation. Harriet identifies as a man now. He goes by different names, depending on which man he feels himself to be. Usually Dragomir, but sometimes Otam, Alex, Holton. I mostly call him Evan. Evan and I speak by phone a few times over the course of the three months that he is in custody. I find myself always uncertain, never clear with whom I am 
speaking. But it feels uncomfortable to me, on picking up the phone and hearing the jail recording announce that "Evan Sawser" is attempting to reach me and accepting the fees, to then, on hearing the familiar voice on the other line, ask: "Who are you today?" It seems like something that you should already know by the time you recognize a voice, particularly when the person on the other end has already been identified by name. It feels like something you should know, but I never do.

I go to visit. Even on my visit, we speak by phone; Evan and I are seated across from each other in a cell split by a thick pane of plastic, with a phone receiver on either side. He sits with his trunk more upright now, feet planted, rather than thighs crossed. He seems bigger to me, stronger. I don't know if that is just my perception, a part of getting to know this new Evan, or if he is putting on weight in custody, now that he has regular access to food. His side of the conversation, which is most of the conversation, rambles, tumbling down various tunnels of fixation, only to be pulled out of one by the discovery of another. I let him speak without stopping him, except for when he veers into soliloquies about the reasons for which he was arrested; the jail records these conversations through the black phone receivers. But other than stopping a discussion about what happened on that night, I don't interrupt him or ask for clarification- even when I don't follow.

At one point, he begins to laugh. He puts the phone down on the metal sill that bifurcates the plastic pane and heaves his body forward. He throws his stillgaunt face toward the plastic, into my own reflection. Images of our eyes - his, across from me through the plastic plane; mine, also across from me in their reflection - align for a split second before he throws himself back and forth in a full-body cackle. The force of his rocking mixes with the volume of the laughter that I can hear in real time, as it exits Evan and echoes in the small chamber in which he is locked, and then again, as the staccato electric version that makes its way through the metal phone cable on a millisecond of delay. He tells me that he saw the psychiatrist yesterday:

He came by, put me on some Abilify. I've never had a reaction that quickly. Harriet came back and sat in the room next to me. She was pissed to be back, so she started to cut off her limbs. It scared me, all the blood, but then some other members of the committee came back and they started killing each other over their traumas. So I think she's gone for now.

Harriet had wandered off. 
And now Evan's speech wanders, on to something else, but I don't really listen. I daydream, remembering a different conversation, one in yet another park rather than in a jail cell, when Evan had asked me if I preferred spending time with Dragomir or with Harriet. I had told him that I was not sure how to answer the question, that I understood that Dragomir and Harriet were different people for him, but that, to me, my experience was of interacting with one person. It was like being surprised by someone, I had tried to explain, like when you learn something new about someone you thought you knew. Evan had laughed at me and had thrown the daisy chain that he had been working on in my face. "That's absurd," he had said, "what is there to be surprised by? When someone surprises you, that just means that they have become someone else. When you know someone, there is no such thing as surprise." I had returned Evan's question: Did Dragomir and Harriet feel differently about me? He could not answer. "I can remember some of Harriet's thoughts, in the distance, but I can't feel her. I can't be responsible for how she felt." I had thought, then, of Harriet's remembrance of the day that she - or one of her-had hurt her mother. She could not account, she had said, for putting her hands on her mother. She could not remember. In Harriet's view, it was surprising that her body had attacked her mother. Harriet loved her mother. She would not have done that. It must have been someone else.

In Harriet's self-professed "cyclical and random" understanding of time, selves blossom and multiply, appearing and disappearing on the edge of that broad landscape, not confined to a single gridded plot point. In configuring space and time as linear, the court had aspired to teach Harriet that selves are singular, that she must take responsibility for the linear past. But in Harriet's involutions of time and space, their "cyclical and random" rotations in which the spatiotemporal coordinates of the court's chronotopic plot unfurl and fan, Harriet sees selves fractionate into different beings, unaccountable to one another, with no sense of linear past to present, no such sense of spatiotemporal or subjective confinement. The state may momentarily succeed at confining Evan to a jail cell for a particular time, but Evan's selves were not learning the court's lessons. After all, Harriet had gotten up and left.

Back in the visiting cell, I keep the phone receiver to my ear, but lean away from the plastic pane. I look out the slit in the heavy door to my back, the one that the guard had closed behind me when I had entered this cell to speak with Evan. The sun glints. I can see the poking tops of a few evergreens. Somewhere, farther off than I can see, over only one mountain ridge, is the Pacific. The land, 
the sea, the air. I want to escape, but instead stay put in my flimsy plastic chair. And when the guard finally comes to open the door, to lead me back into the industrial-sized elevator, down to the lobby, out the front door of the jailhouse, and into the squinty sunlight, I am unsure if I will come back. Part of me wants for time to be linear, to be directional, to afford me the agency to move away from this building and these people, but mostly, away from this feeling.

\begin{abstract}
Based on two years of ethnographic fieldwork in mental health courts in the San Francisco Bay Area, this article juxtaposes the fixity that defines the legal concept of jurisdiction with the itineracy of homeless individuals judged by criminal courts. I assert that jurisdiction is an attempt at control: by invoking jurisdiction, courts attempt to fix people and objects within time and space so as to yield a narrative of liberal accountability for which defendants can be held responsible. Rather than assume the vantage point of the law, I stick with Harriet, a person who was homeless and subject to a mental health court's attempt at control. Moving away from the law exposes when state attempts at control fail. Claims to jurisdiction reflect the state's reliance on control through a particular chronotope of linear time and divisible space. In differently configuring time and space as cyclical and unbounded, Harriet confounds the law's attempt at control. Further, the state's invocation of jurisdiction as a concept that fixes time and space produces unruly affects, or coordinates of relation that escape a rule of law presenting itself as rational. Harriet's relationships with others reflect and enable her escape from state control: they inhabit an affective atmosphere that is produced by the law's own chronotopic terms, but that reject the individual accountability that the law understands as a product of claims to jurisdiction. In paying attention to missed encounters between Harriet and the court, this article reveals and theorizes moments in which power escapes its own terms and enters a social, deindividuated, affective sphere. [affect; law; jurisdiction; social control; state power; subjectivity; homelessness; mental health; criminal courts; the United States]
\end{abstract}

\title{
NOTES
}

Acknowledgments I would like to express my gratitude, first, to Harriet, Dragomir, Evan: I deeply appreciate your repeated willingness to let me into your lives and to explain to me the significance of living them on your own varied terms. I am very grateful to the entire working group at the Santa Clara County Mental Health Court for allowing me to observe and partake in daily life in their courtroom. Many thanks to João Biehl, Lauren Cubellis, Lisa Davis, Adriana Petryna, Tali Ziv, and the members of my writing group, along with Dominic Boyer and three anonymous reviewers, for their insightful feedback on drafts of this article. Versions of this essay were presented at the "Law and Life in Rural America: Cows, Cars, and Criminals" conference sponsored by the Program in American Studies at Princeton University, the "Interlegal Space Times and Ethnographies of Legal Assemblage" panel at the 2016 American Ethnological Society meetings, and the "Ethnographic Explorations of Illegalities, Penalities, and Risk/Security" panel at the 2016 Law and Society Association 
meetings. I thank Celeste Alexander, Elsa Devienne, Philip Goodman, Heath Pearson, Deborah Poole, Emily Prifogle, Lisa Pruitt, Sebastian Ramirez, and Robert Werth for organizing and providing comments at these events. Support for the research and writing of this article was provided by the Wenner-Gren Foundation, the National Science Foundation, the Princeton University Center for Human Values, the Princeton University Program in American Studies, the Princeton University Center for Health and Wellbeing, and a Mellon/ACLS Dissertation Completion Fellowship.

1. The name Harriet is a pseudonym that I use to protect my informant's identity.

2. Harriet's locations within Santa Clara County have also been disguised for her protection. Alta Vista is a pseudonym.

3. Shaunnagh Dorsett and Shaun McVeigh (2012) provide a helpful overview of the jurisprudence of jurisdiction. However, they overdetermine the concept, imputing success to the state's attempt to claim territory through jurisdiction. Their analysis provides little leeway for countermeasures that pull against the state's attempt to assert authority through jurisdiction. For example, their book opens with the statement: "We are brought into life and set in motion according to the authority of law, our conduct is shaped in accordance to civil order, and our conscience created and turned to political faith in law and community. Jurisdictional thinking, so to speak, gives legal form to life and life to law" (Dorsett and McVeigh 2012,1). This type of thinking cannot account for lives like Harriet's, lives that are implicated by but not entirely subject to the law. Complete faith in the efficacy of jurisdiction overestimates the power of law and reifies the state.

4. For more on the link between temporality and power, see Povinelli 2011, Cabatigan 2016, and Thorkelson 2016. Mariana Valverde (2014) suggests that anthropologists analytically foreground temporality over space, a move that I see stemming from the discipline's methodological privileging of space. Because ethnography involves going somewhere, descriptions of place comprise an essential part of ethnographic description. What would ethnography be without descriptions of space? Space, then, is just as important, but is often mistakenly indexed as description rather than argument.

5. While this essay sticks closely to the particularities of Harriet's case, the types of arguments and conceptual differences between court professionals and Harriet were commonplace within the mental health court. Court staff and clients were constantly fighting over the terms of their appearances in court, over whether or not various circumstances were excusable; the mental health court's chronotope was never specific to Harriet, but applied to all clients.

6. Many thanks to Thalia Gigerenzer for drawing my attention to the fundamental relationality invoked by "going missing."

\section{REFERENCES}

Bakhtin, Mikhail M.

1981 "Forms of Time and of the Chronotope in the Novel." In The Dialogic Imagination: Four Essays, 84-258. Translated by Caryl Emerson and Michael Holquist. Austin: University of Texas Press. Originally published in 1975.

Benda-Beckmann, Franz von, and Keebet von Benda-Beckmann

2014 "Places that Come and Go: A Legal Anthropological Perspective on the Temporalities of Space in Plural Legal Orders." In The Expanding Spaces of Law: A Timely Legal Geography, edited by Irus Braverman, Nicholas Blomley, David Delaney, and Alexandre Kedar, 31-52. Stanford, Calif.: Stanford University Press.

Benton, Lauren

2009 A Search for Sovereignty: Law and Geography in European Empires, 1400-1900. New York: Cambridge University Press. 
Bergson, Henri

Cabatigan, Lee

1998 Creative Evolution. Translated by Arthur Mitchell. New York: Dover. Originally published in 1908 .

2016 "Time and Transcendence: Narrating Higher Authority at the Caribbean Court of Justice." Law and Society Review 50, no. 3: 674-702. https://doi.org/ 10.1111 /lasr. 12220 .

Choy, Timothy, and Jerry Zee

2015 “Condition-Suspension.” Cultural Anthropology 30, no. 2: 210-23. https:// doi.org/10.14506/ca30.2.04.

Comaroff, Jean, and John L. Comaroff

2016 The Truth About Crime: Sovereignty, Knowledge, Social Order. Chicago: University of Chicago Press.

Deleuze, Gilles

1986 Cinema 1: The Movement-Image. Translated by Hugh Tomlinson and Barbara Habberjam. Minneapolis: University of Minnesota Press. Originally published in 1983.

Deleuze, Gilles, and Félix Guattari

1987 A Thousand Plateaus: Capitalism and Schizophrenia. Translated by Brian Massumi. Minneapolis: University of Minnesota Press. Originally published in 1980.

Dorsett, Shaunnagh, and Shaun McVeigh

2012 Jurisdiction. New York: Routledge.

Greenhouse, Carol J.

1996 A Moment's Notice: Time Politics Across Cultures. Ithaca, N.Y.: Cornell University Press.

Kahn, Jeffrey S.

2017 "Geographies of Discretion and the Jurisdictional Imagination." Political and Legal Anthropology Review 40, no. 1: 5-27. https://doi.org/10.1111/plar.12205.

Lovell, Anne M.

1997 “'The City is My Mother': Narratives of Schizophrenia and Homelessness.” American Anthropologist 99, no. 2: 355-68. https://doi.org/10.1525/aa.1997. 99.2.355.

Massumi, Brian

2002 Parables for the Virtual: Movement, Affect, Sensation. Durham, N.C.: Duke University Press.

Povinelli, Elizabeth A.

2011 Economies of Abandonment: Social Belonging and Endurance in Late Liberalism. Durham, N.C.: Duke University Press.

Richland, Justin B.

2013 "Jurisdiction: Grounding Law in Language." Annual Review of Anthropology 42: 209-226. https: / / doi.org/10.1146/annurev-anthro-092412-155526.

Stevenson, Lisa

2014 Life Beside Itself: Imagining Care in the Canadian Arctic. Berkeley: University of California Press.

Stewart, Kathleen

2011 “Atmospheric Attunements." Environment and Planning D 29, no. 3: 445-53. https: / / doi.org/10.1068/d9109.

Thomas, Deborah A.

2016 "Time and the Otherwise: Plantations, Garrisons, and Being Human in the Caribbean.” Anthropological Theory 16, nos. 2-3: 177-200. https://doi.org/ $10.1177 / 1463499616636269$.

Thorkelson, Eli

2016 "The Infinite Rounds of the Stubborn: Reparative Futures at a French Political Protest." Cultural Anthropology 31, no. 4: 493-519. https://doi.org/10.14506/ ca31.4.03. 
Valverde, Mariana

2009 “Jurisdiction and Scale: Legal 'Technicalities' as Resources for Theory.” Social and Legal Studies 18, no. 2: 139-57. https://doi.org/10.1177/ 0964663909103622 .

2014 “'Time Thickens, Takes on Flesh': Spatiotemporal Dynamics in Law.” In The Expanding Spaces of Law: A Timely Legal Geography, edited by Irus Braverman, Nicholas Blomley, David Delaney, and Alexandre Kedar, 53-76. Stanford, Calif.: Stanford University Press.

2015 Chronotopes of Law: Jurisdiction, Scale, and Governance. New York: Routledge. 